
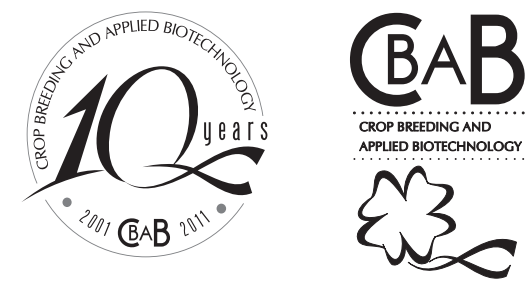

\title{
Determination of the mating system of Tucumã palm using microsatellite markers
}

\author{
Santiago Linorio Ferreyra Ramos ${ }^{1 *}$, Maria Teresa Gomes Lopes ${ }^{1}$, Ricardo Lopes ${ }^{2}$, Raimundo Nonato Vieira da Cunha ${ }^{2}$, Jeferson Luis \\ Vasconcelos de Macêdo $^{2}$, Luis Antônio Serrão Contim ${ }^{3}$, Charles Roland Clement ${ }^{4}$, Doriane Picanço Rodrigues ${ }^{1}$ and Laura Graciliana \\ Bernardes ${ }^{1}$
}

Received 5 August 2010

Accepted 30 September 2010

\begin{abstract}
The Amazonian Tucumã palm (Astrocaryum aculeatum) produces edible fruit, traditionally consumed in indigenous communities and increasingly in urban centers. The species is incipiently domesticated and little studied, despite its growing economic importance for smallholder farmers and gatherers. Studies on the mating system are required for the conservation and use of the species' genetic resources. Our objective was to estimate mating system parameters of the Tucuma palm using microsatellite markers. Plants of 11 progenies of a spontaneous population were genotyped with eight microsatellite loci and the mating system parameters estimated. The population outcrossing rate was estimated at 0.978, and ranged from 0.774 to 1 at the family level. The estimates of the correlation of paternity (0.176 and 0.205) suggest a low probability of full-sibs within progenies. Tucumã palm is a predominantly allogamous species and the open-pollinated progenies consist predominantly of half-sibs.
\end{abstract}

Key words: Astrocaryum aculeatum; palm domestication; microsatellite markers; outcrossing rate; characterization of genetic resources.

\section{INTRODUCTION}

The Tucumã palm (Astrocaryum aculeatum G. Mey., Palmae) is native to Brazilian Amazonia and also found in Guyana, Peru, and Colombia (Henderson 1995). The species is common in areas that are deforested or to some degree degraded under anthropogenic influence. The thin pulp of tucumã fruit is rich in starch, oil and beta-carotene, and highly esteemed as food by the Central Amazonian population, where its economic importance for smallholder farmers and gatherers is growing (Lopes et al. 2009).

The species is almost exclusively exploited by extraction today, although smallholders are starting to plant it, and the variability in spontaneous populations is great for yield and quality traits (e.g., fruit size, pulp yield, taste, fiber and oil content). Only part of the plants in spontaneous populations bear fruit with characteristics that meet consumer preferences; additionally, many plants are unproductive or very tall, making fruit harvest difficult (Schroth et al. 2004). Within the genetic variability available in natural populations, shorter genotypes with high fruit yield, good pulp consistency and taste can be selected (Schroth et al. 2004). These tucumã genotypes can be planted in secondary forests or in agroforestry, agrosilvopastoral or in monoculture systems.

Co-dominant molecular markers have been successfully used in genetic studies of numerous plant species (Alves et al. 2003, Seoane et al. 2005, Karasawa et

\footnotetext{
${ }^{1}$ Universidade Federal do Amazonas (UFAM), Avenida General Rodrigo Otávio Jordão Ramos, 3000, Aleixo, 60.077-000, Manaus, AM, Brazil. *E-mail: santiago.ramos10@hotmail.com

${ }^{2}$ Embrapa Amazônia Ocidental, AM 010, km 29, 69.048-660, Manaus, AM, Brazil

${ }^{3}$ Universidade Federal de Goiás, Campus Jataí, BR 364, km 192, 75.801-615, Jataí, Goiás, Brazil

4 Av. Efigênio Salles, s/n, Aleixo, 69.060-020, Manaus, AM, Brazil
} 
SLF Ramos et al.

al. 2007, Rodrigues et al. 2008, Missio et al. 2009). These markers can also provide information on the outcrossing rate in tucumã progenies that will help define strategies of selection and conservation of plant genetic resources. The use of molecular markers in tucumã progenies obtained from natural populations facilitates the estimation of parameters of the mating system and only requires the collection and germination of randomly selected progenies from fruiting plants in the population (Ritland 2002). These aspects permit a relatively simple and rapid study of the mating system of perennial species where no information on the genetic control of morphological characteristics is available, as in the case of Tucumã palm. The purpose of this study was to estimate parameters of the mating system in tucumã palm progenies using microsatellite markers.

\section{MATERIAL AND METHODS}

Of the 11 open-pollinated progenies, nine had 25 plants, one 24 and one 21 , totaling 270 plants. The progenies were collected from plants of a spontaneous population on the Najatuba farm, on the left bank of the Igarapé Tarumã-Açú, Manaus, Amazonas, Brazil (lat $02^{\circ} 53$ '22.1" $\mathrm{S}$, long $60^{\circ} 06^{\prime} 11.6^{\prime}$ W). The fruits were harvested in April 2006 and germinated in the Palm Oil and Agro-energy Laboratory of Embrapa Amazônia Ocidental.

Leaf samples of the mother plants and progenies were collected and packed in plastic bags with silica gel for further analysis. DNA was extracted at the Laboratory of Plant Biotechnology, University Center Nilton Lins, Manaus, AM, with the modified CTAB method (Murray and Thompson 1980). After extraction, the genomic DNA was quantified in agarose gel $0.8 \%$ (w/v), stained with ethidium bromide, and observed under UV light, based on comparisons with molecular mass standards of 50, 100 and $200 \mathrm{ng} \mathrm{mL}^{-1}$ DNA lambda phage (Invitrogen).

The microsatellite loci were amplified at the Applied Evolution Laboratory, Federal University of Amazonas, Manaus, Brazil. Six microsatellite loci were amplified with primers developed for peach palm (Bactris gassipaes) by Billotte et al. (2004) mBg41, mBg58, mBg62, mBg66, mBg77, and $\mathrm{mBg} 91$, and two by Martínez et al. (2002), Bg17 and $\mathrm{Bg} 55$, and transferred to Tucumã palm. The PCR reaction contained: $4.0 \mathrm{~mL}$ de DNA (10 $\left.\mathrm{ng} \mathrm{mL}^{-1}\right) ; 1.0 \mathrm{~mL}$ buffer Tp10X; 1.0mLdNTP(2.5 mM); $1.0 \mathrm{mLMgCl}_{2}(25 \mathrm{mM}) ; 1.0 \mathrm{~mL}$ reverse primer $(2.5 \mathrm{mM}) ; 0.5 \mathrm{~mL}$ forward primer $(2.5 \mathrm{mM})$; $0.5 \mathrm{~mL}$ fluorescent primer M13 Hex or Fam (5 mM); $0.2 \mathrm{~mL}$ Easy Taq DNA polymerase ( $5 \mathrm{U} \mathrm{mL}^{-1}$ ) (LGC Biotecnologia, São Paulo, Brasil) and $0.8 \mathrm{~mL}$ mili-Q $\mathrm{H}_{2} \mathrm{O}$. Amplification was performed in a thermocycler (Eppendorff) in two steps: 1) initial denaturation $\left(94^{\circ} \mathrm{C}, 2 \mathrm{~min}\right.$.), annealing ( $\mathrm{mBg} 77$ $58{ }^{\circ} \mathrm{C}, 20 \mathrm{sec}$. and the other primers $52{ }^{\circ} \mathrm{C}, 20 \mathrm{sec}$.), 25 amplification cycles $\left(94{ }^{\circ} \mathrm{C}, 10 \mathrm{sec}\right.$.) and a final extension $\left(72{ }^{\circ} \mathrm{C}, 30 \mathrm{sec}.\right)$, and 2$)$ denaturation $\left(72{ }^{\circ} \mathrm{C}, 15 \mathrm{~min}\right.$. $)$, annealing $\left(50^{\circ} \mathrm{C}, 20 \mathrm{sec}\right.$.), 20 amplification cycles $\left(94^{\circ} \mathrm{C}\right.$, $10 \mathrm{sec}$.) and final extension $\left(72^{\circ} \mathrm{C}, 30 \mathrm{~min}\right.$.). The fluorescent products were analyzed in an automated sequencer (Mega Base 1000) at the Molecular Biology Thematic Laboratory of the National Research Institute of Amazonia - INPA, and the allele size (bp) estimated with the program Fragment Profiler and the molecular weight marker ET-400-ROX (GE Healthcare, England).

Estimates of mating system parameters were obtained according to the mixed mating and correlated crossing models (Ritland 2002) using the program Multilocus Mating System Program - MLTR (Ritland 2004), based on the probabilities of Expectation Maximization (EM) and Newton-Raphson (NR). The following parameters were estimated: i) multilocus population outcrossing rate $\left(t_{m}\right)$; ii) single locus population outcrossing rate $\left(t_{s}\right)$; iii) outcrossing rate of related individuals $\left(t_{m}-t_{s}\right)$; iv) correlation of the estimate of $t\left(r_{t}\right)$; v) correlation of paternity $\left(r_{p}\right)$; and vi) correlation of selfing $\left(r_{s}\right)$. The individual multilocus outcrossing rate $\left(t_{m}\right)$ was estimated by the method of moments (MME). The standard deviation of estimates was estimated by 1000 bootstrap resamplings. Resampling units were plants of a progeny for the individual outcrossing rate of a progeny and among progenies for the population outcrossing rate.

The coefficient of coancestry among plants within progenies $\left(\theta_{x y}\right)$ was estimated from the correlation coefficient of relatedness among plants within progenies $\left(r_{x y}\right)$, as proposed by Ritland (1989): $\hat{r}_{x y}=0,25\left(1+\hat{F}_{a}\right)\left[4 \hat{s}+\left(\hat{\mathrm{t}}_{m}^{2}+\hat{\mathrm{t}}_{m} \hat{s}_{s}\right)\left(1+\hat{r}_{p}\right)\right]$, where $s$ is the selfing rate $\left(\hat{s}=1-\hat{t}_{m}\right)$. In diploid species, the coefficient $\theta_{x y}$ is half the coefficient $r_{x y}$ (Lynch and Walsh 1998): $\theta_{x y}=\hat{x}_{x y} / 2$. The effective size of variance $\hat{N}_{e(v)}=0.5 /\left(r_{x y} / 2\right)$ was estimated according to Cockerham (1969).

\section{RESULTS AND DISCUSSION}

The multilocus population outcrossing rate $\left(t_{m}\right)$ was 0.978 for both algorithms (EM and NR) used to maximize the likelihood function, with a standard deviation of 0.024 in the estimate obtained by EM and of 0.077 by NR (Table 1). Hence, the estimates do not differ statistically from one, indicating that the progenies originated by outcrossing 
Determination of the mating system of Tucumã palm using microsatellite

Table 1. Estimates of inbreeding, relatedness and mating system of an Astrocaryum aculeatum population in Manaus, Amazonas

\begin{tabular}{|c|c|c|c|c|}
\hline \multirow{2}{*}{ Estimate } & \multicolumn{4}{|c|}{ Outcrossing rate } \\
\hline & \multicolumn{4}{|c|}{ Method MME } \\
\hline Family $1-t_{m}$ & \multicolumn{4}{|c|}{$0.948(0.149)[25]$} \\
\hline Family $2-t_{m}$ & \multicolumn{4}{|c|}{$1.036(0.052)[21]$} \\
\hline Family $3-t_{m}$ & \multicolumn{4}{|c|}{$1.038(0.013)[25]$} \\
\hline Family $4-t_{m}$ & \multicolumn{4}{|c|}{$1.046(0.032)[25]$} \\
\hline Family $5-t_{m}$ & \multicolumn{4}{|c|}{$0.986(0.098)[25]$} \\
\hline Family $6-t_{m}$ & \multicolumn{4}{|c|}{$1.055(0.012)[25]$} \\
\hline Family $7-t_{m}$ & \multicolumn{4}{|c|}{$1.090(0.000)[25]$} \\
\hline Family $8-t_{m}$ & \multicolumn{4}{|c|}{$1.022(0.051)[25]$} \\
\hline Family $9-t_{m}$ & \multicolumn{4}{|c|}{$1.283(0.035)[24]$} \\
\hline Family $10-t_{m}$ & \multicolumn{4}{|c|}{$1.111(0.110)[25]$} \\
\hline \multirow[t]{2}{*}{ Family $11-t_{m}$} & \multicolumn{4}{|c|}{$0.774(0.171)[25]$} \\
\hline & \multicolumn{2}{|c|}{ Method EM } & \multicolumn{2}{|c|}{ Method NR } \\
\hline Multilocus outcrossing rate $-t_{m}$ & 0.978 & $(0.024)$ & 0.978 & $(0.077)$ \\
\hline Unilocus outcrossing rate $-t_{s}$ & 0.978 & $(0.019)$ & 0.984 & $(0.035)$ \\
\hline Biparental inbreeding/endogamy - $t_{m}-t_{s}$ & -0.001 & $(0.023)$ & -0.007 & $(0.070)$ \\
\hline Correlation of the estimate of $\mathrm{t}-r_{s}$ & 0.276 & $(0.071)$ & 0.444 & $(0.320)$ \\
\hline Correlation of the estimate of multilocus $\mathrm{p}-r_{p}$ & 0.176 & $(0.037)$ & 0.205 & $(0.044)$ \\
\hline Correlation of $\mathrm{t}$ between loci - Selfing rate due to uniparental inbreeding/endogamy $-r_{s}$ & 0.898 & $(0.003)$ & 1.200 & $(0.500)$ \\
\hline Selfing rate due to biparental inbreeding/endogamy $-1-r_{s}$ & 0.102 & & -0.200 & \\
\hline Number of pollen donors $-1 / r_{p}$ & 5.682 & & 4.878 & \\
\hline Selfing rate $-\hat{s}=1-\hat{t}_{m}$ & 0.022 & & 0.022 & \\
\hline Parental fixation index $-F$ & 0.000 & $(0.000)$ & -0.112 & $(0.055)$ \\
\hline Coancestry within progenies $-\theta_{x y}$ & 0.133 & & 0.119 & \\
\hline Effective size of variance $-\hat{N}_{e(v)}$ & 3.748 & & 4.188 & \\
\hline
\end{tabular}

[]-number of plants per progeny; ( ) standard deviation .

and that the species is allogamous. High outcrossing estimates have been found for other palms, e.g., Astrocarium mexicanum (Eguiarte et al. 1992). The single locus population outcrossing rate $\left(t_{s}\right)$ was estimated at $0.978 \pm 0.019$ by EM and at $0.984 \pm 0.035$ by NR. The differences between the estimates of the single-locus and multilocus population outcrossing rate $\left(t_{m}-t_{s}\right)$ were -0.001 $\pm 0.023(\mathrm{EM})$ and $-0.007 \pm 0.070(\mathrm{NR})$ and statistically not different from zero, indicating absence of crosses between relatives in the population. According to Ritland (2002), for low levels of selfing $(\hat{s}<0.2)$, the correlation $t$ between loci $\left(r_{s}\right)$ corresponds to the inbreeding fraction due to uniparental inbreeding and to the selfing fraction due to biparental inbreeding $\left(1-r_{s}\right)$ ). The correlation $t$ between loci indicates that selfing contributes with $89.8 \%$ of the inbreeding by EM and with $100 \%$ by NR, indicating a low proportion of biparental inbreeding, in agreement with the absence of crosses among relatives.

The estimate of the correlation of selfing $\left(r_{t}\right)$, which represents the probability of finding a plant generated by selfing in a progeny where there is another also generated by selfing, was $0.276 \pm 0.071$ by EM and $0.444 \pm 0.320$ by
NR, indicating minor variation in the individual outcrossing rate. Outcrossing rates at the multilocus individual family level $\left(t_{m}\right)$ did not differ from 1.0, except for family $11\left(t_{m}=\right.$ $0.774 \pm 0.171)$, suggesting variation for selfincompatibility. Seoane et al. (2005) argued that significant correlations of self-pollinations or variations in individual outcrossing rates may indicate the existence of selfincompatibility in the species. Other factors are also emphasized, e.g., populations structured in families and flowering asynchrony, which may contribute to or cause the occurrence of variation in individual outcrossing rates. Low $r_{t}$ estimates indicate that selfed plants are randomly distributed among the progenies and there was no tendency of some mother plants to generate more plants by selfing or by crosses than others.

The paternity correlation $\left(r_{p}\right)$, which indicates the proportion of plants generated by biparental crosses, that is full-sibs (Ritland 1989), was low $(0.176 \pm 0.037$ by EM and $0.205 \pm 0.044$ by NR), revealing randomness in the process of cross-pollination, with few correlated crossings. This result also indicated that most progenies were from crosses of different pollen sources; the number 
of pollen donors $\left(1 / r_{p}\right)$ was estimated at $5.7(\mathrm{EM})$ and 4.9 (NR). Seoane et al. (2005) found between 4.5 and 9 effective pollen donors in a study of Euterpe edulis. The low estimates of correlation of paternity indicate a high number of pollen donors (Ritland 1989).

The fixation index of mother plants $(F$ ) estimated for the progenies was $0.0(\mathrm{EM})$ and $-0.112(\mathrm{NR})$, indicating absence of inbreeding in the mother plants from which the seeds had been collected. Ritland and Jain (1981) explained that the negative value of, by the NR method, is a subterfuge of the algorithm due to the higher than expected frequency of heterozygous genotypes, unlike in the case of the EM algorithm, where the estimators are restricted to values between zero and unity only.

The mean coefficient of coancestry within progenies $\left(q_{x y}\right)$ was $0.133(\mathrm{EM})$ and $0.119(\mathrm{NR})$, close to the expected values in half-sib progenies $(0.125)$. This coefficient is a measure of relatedness that indicates the probability that two randomly sampled alleles in two plants are identical by descent. The coancestry in the progenies of the study population means there is a probability of $13.3 \%$ (EM) or $11.9 \%$ (NR) that two alleles sampled in two plants of the same progeny are identical by descent. Knowing the coefficient of coancestry is also important to estimate the effective variance size (), which measures the genetic representativeness of progenies compared to the reference population. In samples of progenies of a population of infinite size, the effective variance size would range between one (1) and four (4); 1 would represent a selfed progeny, 2 full-sib progenies and 4 half-sib progenies (Giudice Neto et al. 2005). The effective size of variance was estimated at 3.75 (EM) and $4.19(\mathrm{NR})$, indicating that the genetic representativeness in the progenies is expected to be close to that expected in randomly mated progenies, which agrees with previous results indicating that the progenies are predominantly half-sibs.

The Tucumã palm is predominantly allogamous and the open-pollinated progenies generally consist of halfsibs. In spontaneous Tucumã populations the variability for traits such as growth rate in height, yield, and fruit quality is considerable (Lopes et al. 2009). Information on the mating system of natural Astrocaryum aculeatum populations is extremely useful to guide programs for genetic conservation, domestication and breeding of populations (Oliveira et al. 2003).

\section{ACKNOWLEDGEMENTS}

The authors wish to thank the Financiadora de Estudos e Projetos (FINEP) and Fundação de Amparo à Pesquisa do Estado do Amazonas (FAPEAM) for funding the project CTIAFAM - Process 01.06.0380.04 and the Conselho Nacional de Pesquisa e Desenvolvimento (CNPq) for funding the project BIOPALM - Process 553254/ 2005-7 and granting the first author a scholarship.

\title{
Determinação do sistema reprodutivo do tucumã-do- Amazonas com marcadores microssátelites
}

\begin{abstract}
RESUMO - A palmeira Astrocaryum aculeatum produz frutos comestíveis, utilizados na alimentação por populações indígenas, tradicionais e urbanas. Esta espécie é incipientemente domesticada e pouco estudada apesar de sua importância econômica para pequenos produtores e extrativistas. Estudos do sistema reprodutivo são necessários para conservação e uso dos recursos genéticos da espécie. O objetivo foi estimar parâmetros do sistema reprodutivo do tucumã-do-Amazonas usando marcadores microssatélites. Plantas de 11 progênies de uma população espontânea foram genotipadas com oito locos de microssatélites e os parâmetros do sistema de cruzamento estimados. A estimativa da taxa de cruzamento populacional foi de 0,978, enquanto ao nível de família variou de 0,774 a 1,283. Os valores da correlação de paternidade, 0,176 e 0,205, indicam baixa probabilidade da ocorrência de irmãos completos dentro das progênies. O tucumã-do-Amazonas é predominantemente alógama e as progênies de polinização aberta são constituídas predominantemente por meio-irmãos.
\end{abstract}

Palavras-chave: Astrocaryum aculeatum; domesticação de palmeira; marcadores microssatélites; taxa de cruzamento; caracterização de recursos genéticos. 


\section{REFERENCES}

Alves RM, Artero AS, Sebbenn AM and Figueira A (2003) Mating system in a natural population of Theobroma grandiflorum (Willd. Ex Spreng) Schum. by microsatellite markers. Genetics and Molecular Biology 26: 373-379.

Billote N, Couvreur T, Marseillac N, Brottier P, Perthuis B, Vallejo M, Noyer JL, Jacquemoud-Collet JP, Risterucci AM and Pintaud JC (2004) A new set of microsatellite markers for the peach palm (Bactris gasipaes Kunth): characterization and acrosstaxa utility within the tribe Cocoeae. Molecular Ecology Notes 4: 580-582.

Cockerham CC (1969) Variance of gene frequency. Evolution 23: 72-84.

Eguiarte LE, Perez-Nasser N and Piñero D (1992) Genetic structure, outcrossing rate and heterosis in Astrocaryum mexicanum (Tropical Palm): implications for evolution and conservation. Heredity 69: 217-228.

Giudice Neto JD, Sebbenn AM and Kageyama PY (2005) Sistema de reprodução em Caesalpinia echinata Lam. implantada em arboreto experimental. Revista Brasileira de Botânica 28: 409-418.

Henderson A (1995) The palms of the Amazon. Oxford University Press, New York, 362p.

Karasawa MMG, Vencovsky R, Silva CM, Zucchi M, Oliveira GCX and Veasey EA (2007) Mating system of Brazilian Orysa glumaepatula populations studied with microsatellite markers. Annals of Botany 99: 254-253.

Lopes MTG, Macêdo JLV, Lopes R, van Leeuwen J, Ramos SLF and Bernardes LG (2009) Domesticação e melhoramento do tucumã-do-Amazonas. In Borém A, Lopes MTG and Clement CR (Org.) Domesticação e melhoramento: espécies amazônicas. UFV, Viçosa, p. 425-442.

Lynch M and Walsh B (1998) Genetics and analysis of quantitative traits. Sinauer Associates, Sunderland, 980p.

Martínez AK, Gaitán-Solis M, Duque MC, Bernal R and Tohme J (2002) Microsatellite loci in Bactris gasipaes (Arecaceae): their isolation and characterization. Molecular Ecology Notes 2: 408-410
Missio RF, Caixeta ET, Zambolim EM, Zambolim L, Cruz CD and Sakiyama NS (2009) Polymorphic information content of SSR markers for Coffea spp. Crop Breeding and Applied Biotechnology 10: 89-94.

Murray MG and Thompson WF (1980) Rapid isolation of highmolecular weight plant DNA. Nucleic Acids Research 8: 4321-4326.

Oliveira MSP, Couturier G and Beserra P (2003) Biologia da polinização da palmeira tucumã (Astrocaryum vulgare Mart.) em Belém, Pará, Brasil. Acta Botânica Brasileira 17: 343353.

Ritland K and Jain S (1981) A model for the estimation of outcrossing rate and gene frequencies using independent loci. Heredity 47: 35-52.

Ritland K (1989) Correlated matings in the partial selfer Mimulus guttatus. Evolution 43: 848-859.

Ritland K (2002) Extensions of models for the estimation of mating systems using $n$ independent loci. Heredity 88: 221228.

Ritland K (2004) Multilocus mating system program - MLTR version 3.0. University of British Colombia, Vancouver. Available at <http://genetics.forestry.ubc.ca/ritland/ programs.htlm> Accessed on Sept 3, 2007.

Rodrigues DH, Alcântara Neto F and Schuster I (2008) Identification of essentially derived soybean cultivars using microsatellite markers. Crop Breeding and Applied Biotechnology 8: 74-78.

Schroth G, Mota MSS, Lopes R and Freitas AF (2004) Extractive use, management and in situ domestication of a weedy palm, Astrocaryum tucuma, in the Central Amazon. Forest Ecology and Management 202: 161-179.

Seoane CES, Sebbenn AM and Kageyama PY (2005) Sistema de reprodução em duas populações naturais de Euterpe edulis Mart. sob condições de fragmentação florestal. Scientia Forestalis 69: $13-24$. 